\title{
Penerapan Model Pembelajaran Kooperatif Tipe Make A Match Untuk Meningkatkan Hasil Belajar
}

\author{
Heri Kurnia ${ }^{1}$ dan Gilang Septera ${ }^{2}$ \\ ${ }^{1}$ Pendidikan Pancasila dan Kewarganegaraan, Universitas Cokroaminoto Yogyakarta \\ Jl. Perintis Kemerdekaan, Gambiran, Umbulharjo, Kota Yogykarta 55161 \\ ${ }^{2}$ Sekolah Menengan Atas Negeri 1 Cikatomas, Tasikmalaya, Jawa Barat \\ Jl. Raya Cikatomas No. 109, Cayur, Cikatomas, Tasikmalaya, Jawa Barat 46193 \\ ${ }^{1}$ Email: herikurnia@ucy.ac.id \\ ${ }^{2}$ Email:gilangseptera@gmail.com
}

\begin{abstract}
ABSTRAK
Penelitian ini dilatar belakangi oleh pembelajaran di SMA Negeri 1 Cikatomas, Kabepaten Tasikmalaya, bahwa teknik pembelajaran yang digunakan masih kurang menarik bagi siswa, sehingga motivasi dan prestasi belajar siswa untuk belajar relatif rendah. Mengingat hal tersebut, sebaiknya penyampaian pelajaran dengan model pembelajaran yang menarik sangat diharapkan, karena aktivitas belajar pada anak tergantung pada cara guru dalam menyampaikan pelajaran. Oleh karena itu peneliti menggunakan model pembelajaran kooperatif tipe make a match dalam meningkatkan hasil belajar PKn siswa.

Penelitian ini merupakan penelitian tindakan kelas (PTK). Dalam PTK tahap penelitian terdiri atas empat tahap, yaitu perencanaan, pelaksanaan tindakan, observasi dan refleksi. Hasil Penelitian menunjukkan bahwa penerapan model pembelajaran kooperatif tipe make a match dapat meningkatkan hasil belajar PKn siswa. Hal ini ditunjukkan dengan Tingkat ketuntasan belajar juga meningkat dari tes awal yaitu $45 \%$, pada siklus I menjadi 56\% dan pada siklus II naik menjadi $82 \%$.

Kesimpulan penelitian ini adalah dengan penerapan model pembelajaran kooperatif tipe make a match dapat meningkatkan hasil belajar PKn siswa kelas kelas XI IPS 3 SMA Negeri 1 Cikatomas dengan jumlah siswa 29 orang.

Kata kunci: hasil belajar PKn, model pembelajaran kooperatif tipe make a match
\end{abstract}

\begin{abstract}
This research is motivated by learning at SMA Negeri 1 Cikatomas, Kabepaten Tasikmalaya, that the learning techniques used are still less attractive to students, so students' motivation and learning achievement for learning is relatively low. In view of this, it is better to deliver lessons with an interesting learning model that is expected, because learning activities in children depend on the way the teacher presents the lesson. Therefore, researchers use the cooperative model of make a match type of learning in improving student Civics learning outcomes.

This research is a classroom action research (CAR). In the CAR research stage consists of four stages, namely planning, implementing actions, observing and reflecting. The results showed that the application of the make a match type of cooperative learning model could improve student Civics learning outcomes. This is indicated by the level of mastery learning also increased from the initial test of 45\%, in the first cycle to $56 \%$ and in the second cycle rose to $82 \%$.
\end{abstract}


The conclusion of this research is the application of the make a match type of cooperative learning model can improve the learning outcomes of PKn class XI IPS 3 students of SMA Negeri 1 Cikatomas with 29 students.

Keywords: Civics learning outcomes, cooperative learning models make a match type

\section{PENDAHULUAN}

Proses pendidikan adalah persemaian dari kehidupan moral suatu masyarakat serta revitalisasi moral masyarakat itu sendiri. Untuk itu, pendidikan mempunyai peranan dalam perkembangan kepribadian manusia. Pendidikan bukan semata-mata transmisi kebudayaan secara pasif tetapi perlu mengembangkan kepribadian yang kreatif. Sekolah sebagai pranata sosial harus kondusif untuk dapat mengembangkan kepribadian yang kreatif. Hal ini sesuai dengan tujuan pendidikan nasional dalam Undang-Undang No. 20 Tahun 2003 tentang Sistem Pendidikan Nasional, yang menyatakan bahwa:

Pendidikan nasional untuk mengembangkan kemampuan dan membentuk watak serta peradaban bangsa yang bermartabat dalam rangka mencerdaskan kehidupan bangsa, bertujuan untuk berkembangnya potensi peserta didik agar menjadi manusia yang beriman dan bertakwa terhadap Tuhan Yang Maha Esa, berakhlak mulia, sehat, berilmu, cakap, kreatif, mandiri dan menjadi warga negara yang demokratis dan bertanggung jawab.

Untuk mewujudkan tatanan kehidupan bangsa yang bermartabat sesuai dengan permasalahan di atas, maka di perlukan suatu sistem pendidikan yang baik sehingga dapat menunjang segala aspek kehidupan manusia. Upaya memperbaiki mutu pendidikan yang ada sekarang ini salah satunya dengan mengembangkan potensi peserta didik untuk aktif, kreatif dan mandiri dalam proses pembelajaran. Hal ini sesuai dengan tujuan pendidikan nasional yang tercantum dalam Undang-Undang No. 20 Tahun 2003 tentang Sistem Pendidikan Nasional tersebut

Pembelajaran PKn disekolah bertujuan agar peserta didik mampu mengembangkan pengetahuan dan keterampilan yang berguna bagi dirinya dalam kehidupan masyarakat, berbangsa dan bernegara. Dalam proses pembelajaran PKn diperlukan adanya keaktifan, supaya peserta didik mampu mengembangkan pola pemikirannya sehingga dapat berpikir kreatif dan rasional. Hal ini sesuai dengan tujuan PKn yang terdapat dalam peraturan Menteri Pendidikan Nasional RI No. 22 tahun 2006 tentang standar isi untuk satuan pendidikan dasar dan menengah dalam dasim budimansyah (2010, h. 121-122) adalah agar peserta didik memiliki kemampuan sebagai berikut:

1. Berpikir secara kritis, rasional dan kreatif dalam menanggapi isu kewarganegaraan. 
2. Berpartisipasi aktif dan bertanggungjawab, dan bertindak secara cerdas dalam kegiatan bermasyarakat, berbangsa, dan bernegara.

3. Berkembang secara positif dan demokratis untuk membentuk diri berdasarkan pada karakter-karakter masyarakat Indonesia agar dapat hidup bersama dengan bangsabangsa lainya.

4. Berinteraksi dengan bangsa-bangsa lain dalam percaturan dunia secara langsung atau tidak langsung dengan memanfaatkan teknologi informasi dan komunikasi.

Uraian di atas menunjukan bahwa PKn memiliki potensi dan posisi strategis untuk mengantarkan dalam membentuk warga negara yang baik, kreatif, bertanggung jawab, cerdas, kritis, dan partisipatif. Sebagai salah satu mata pelajaran sosial yang penting sebagai usaha dalam meningkatkan keterampilan warga negara di dalam membangun negara yang mampu mensejajarkan diri dengan negara lain.

Pada pembelajaran PKn sendiri kreativitas belajar memiliki peran dalam menentukan keberhasilan salam proses pembelajaran. Dalam pembelajaran PKn sebaiknya peserta didik bukan hanya sebagai pendengar saja, akan tetapi siswa juga dituntut untuk terlibat dan aktif dalam proses pembelajaran.

Berawal Berdasarkan observasi yang dilakukan di SMA negeri 1 Cikatomas beralamat di Desa Pakemitan Kecamatan Cikatomas masih banyak permasalahan yang ditemui dalam proses pembelajaran PKn di sana. Hal ini dibenarkan oleh Bapak Irman Nur Hendra selaku guru PPKn di SMA Negeri 1 Cikatomas bahwasannya nilai peserta didik kelas XI khususnya kelas XI IPS 3 pada mata pelajaran PKn cenderung rendah.

Mata Pelajaran Pendidikan Kewarganegaraan dianggap membosankan bagi peserta didik karena cakupan materinya yang cukup luas dan penggunaan model pembelajaran yang monoton yaitu pembelajaran didominasi oleh guru. Peserta didik lebih banyak menggunakan indera pendengarannya dibandingkan dengan indera penglihatannya sehingga apa yang telah mereka pelajari tersebut akan cenderung dilupakan Disamping itu peserta didik juga dituntut untuk mampu menghafalnya sehingga peserta didik kurang bergairah untuk mempelajarinya.

Aktifitas dalam proses pembelajaran kebanyakan didominasi oleh guru dan kurang mellibatkan keaktifan peserta didik, peserta didik hanya menjadi objek pembelajaran sehingga peserta didik kurang mandiri dan mengakibatkan peserta didik menjadi pasif. Proses pembelajaran PPKn di kelas kebanyak diarahkan pada kemampuan peserta didik untuk mengingat dan menimbun berbagai informasi tanpa dituntuk untuk mengembangkan kemampuan berpikirnya tidak sedikit peserta didik yang mengalami kesulitan dalam mengikuti mata pelajaran ini karena model pembelajaran yang digunakan 
oleh guru dirasa kurang tepat, adanya kelemahan dan pelaksanaan proses belajar mengajar PPKn ini berdampak terhadap kualitas akademik/hasil belajar peserta didik hal ini apabila dibiarkan terus berkelanjutan akan mengakibatkan tidak tercapainya tujuan pembelajaran yang diharapkan secara maksimal.

Permasalahan yang digambarkan di atas, baik yang menyangkut rendahnya kualitas prestasi akademik/ hasil belajar peserta didik dalam mata pelajaran PKn, maupun kurangnya kemampuan penyampaian materi oleh guru, serta adanya sikap yang kurang positif dari peserta didik dan masyarakat terhadap mata pelajaran PPKn merupakan suatu tantangan yang harus dihadapi oleh guru. Melihat kondisi tersebut, maka guru dituntut untuk lebih kreatif dan profesional serta mampu menggunakan pengetahuan dan kecakapannya dalam memilih model pembelajaran yang tepat, yaitu yang dapat menumbuhkan minat peserta didik terhadap mata pelajaran khususnya PPKn.

Berdasarkan persoalan di atas, penulis mencoba salah satu cara yang bisa digunakan untuk mengatasi hal tersebut dan untuk lebih meningkatkan pemahaman konsep serta sebagai upaya untuk meningkatkan hasil belajar peserta didik, perlu dikembangkannya suatu model pembelajaran yang tepat. Salah satu model pembelajaran kooperatif adalah make a match (mencari pasangan) yang dikembangkan oleh Lorna Curran yang diterapkan peneliti dalam penelitian ini. Model pembelajaran make a match ini mengajak peserta didik untuk mencari jawaban terhadap suatu pertanyaan atau pasangan dari suatu konsep melalui suatu permainan kartu pasangan. Dengan menggunakan model pembelajaran make a match (mencari pasangan) ini, diharapkan dalam proses pembelajaran peserta didik tidak merasa jenuh dan diharapkan pula dapat meningkatkan pemahaman bagi peserta didik.

\section{METODE PENELITIAN}

\section{Prosedur Pelaksanaan Penelitian}

Menurut Supardi (2010, h. 17-19) ada empat tahapan penting dalam penelitian tindakan, yaitu tahap perencanaan, pelaksanaan, pengamatan, dan refleksi. Keempat tahap dalam penelitian tindakan tersebut adalah unsur untuk membentuk sebuah siklus, yaitu satu putaran kegiatan beruntun yang kembali kelangkah semula. 
Gambar 1 Siklus Penelitian Tindakan Kelas

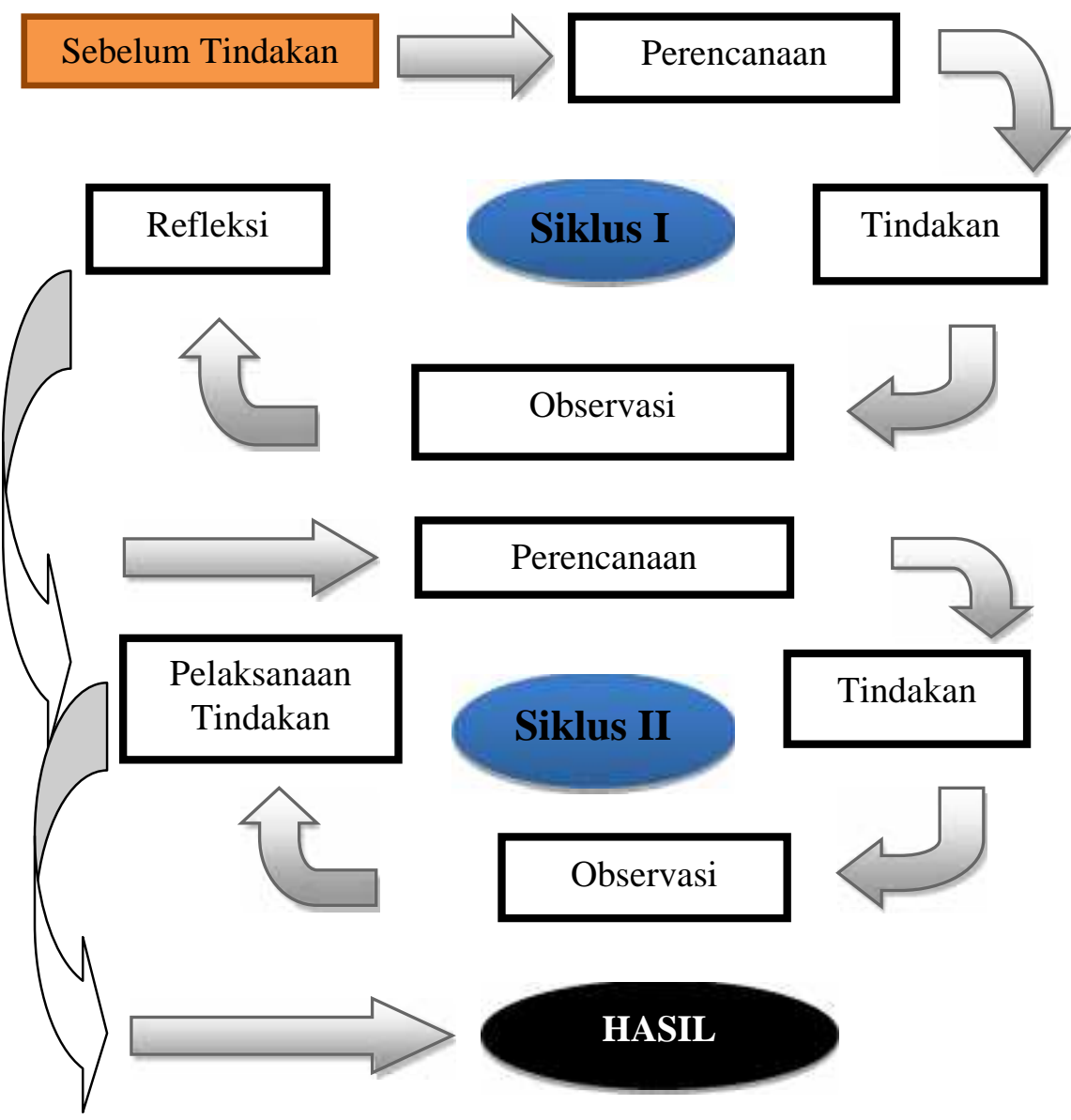

Berdasarkan siklus penelitian di atas, tahapan penelitian adalah sebagai berikut: sebelum tindakan, perencanaan, tindakan, observasi dan refleksi.

\section{Subjek Penelitian}

Penelitian ini akan dilaksanakan di SMA Negeri 1 Cikatomas yang bahwa peserta didiknya cenderung rendah dalam hal hasil belajar

\section{Objek Penelitian}

Objek penelitian adalah peserta didik kelas XI IPS 3 SMAN 1 Cikatomas dengan jumlah siswa 29 orang. Alasan peneliti mengambil lokasi ini adalah karena dalam pelaksanaannya proses belajar memungkinkan untuk melakukan tindakan dengan menggunakan model pembelajaran make a match. Mengingat rata-rata minat peserta didik cenderung ke arah eksakta yang juga terbiasa mengguakan model sejenis. Sehingga, diharapkan dengan menggunakan model yang serupa dapat meningkatkan prestasi peserta didik dalam mata pelajaran PKn. 


\section{HASIL PENELITIAN DAN PEMBAHASAN}

\section{Hasil Penelitian Siklus I}

Berikut ini hasil observasi:

Tabel 1 Hasil Observasi penilaian RPP untuk guru pada Siklus I

\begin{tabular}{|c|c|c|}
\hline No & Indikator Aspek yang diamati & Skor \\
\hline 1. & $\begin{array}{l}\text { Kejelasan perumusan tujuan pembelajaran (tidak } \\
\text { menimbulkan penafsiran ganda dan mengandung } \\
\text { perilaku hasil belajar). }\end{array}$ & 3 \\
\hline 2. & $\begin{array}{l}\text { Pemilihan materi ajar (sesuai dengan tujuan dan } \\
\text { karakteristik peserta didik). }\end{array}$ & 3 \\
\hline 3. & $\begin{array}{l}\text { Pengorganisasian materi ajar (keruntutan, sistematika } \\
\text { materi dan kesesuaian dengan alokasi waktu). }\end{array}$ & 3 \\
\hline 4. & $\begin{array}{l}\text { Pemilihan sumber/media pembelajaran (sesuai dengan } \\
\text { tujuan, materi dan karakteristik peserta didik). }\end{array}$ & 4 \\
\hline 5. & $\begin{array}{l}\text { Kejelasan skenario pembelajaran (setiap langkah } \\
\text { tercermin strategi/metode dan alokasi waktu pada } \\
\text { setiap tahap). }\end{array}$ & 3 \\
\hline 6. & $\begin{array}{l}\text { Kerincian skenario pembelajaran (setiap langkah } \\
\text { tercermin strategi/metode dan alokasi waktu pada } \\
\text { setiap tahap). }\end{array}$ & 3 \\
\hline 7. & Kesesuaian teknik dan tujuan pembelajaran & 4 \\
\hline \multirow[t]{3}{*}{8.} & $\begin{array}{l}\text { Kelengkapan instrumen (soal, kunci, pedoman } \\
\text { penskoran). }\end{array}$ & 3 \\
\hline & Skor Total & 26 \\
\hline & $\begin{array}{l}\text { Persentase nilai RPP } \sum \text { Skor Total } \times 100 \% \\
\text { ¿Skor maksimal seluruh aktifitas (40) }\end{array}$ & $65 \%$ \\
\hline
\end{tabular}

Kriteria:

5 = Sangat Baik

4 = Baik

3 = Cukup

2 = Kurang

1 = Sangat Kurang

\section{Sumber: di olah Peneliti (2015)}

$$
\begin{aligned}
& \text { Penilaian: } \\
& 80 \%-100 \%=\text { Sangat Baik } \\
& 60 \%-79,9 \%=\text { Baik } \\
& 40 \%-59,9 \%=\text { Cukup } \\
& 20 \%-39,9 \%=\text { Kurang }
\end{aligned}
$$

Berdasarkan hasil observasi Penilaian Rencana Pelaksanaan Pembelajaran untuk guru (peneliti) pada siklus I, mendapatkan jumlah persentase sebesar $65 \%$ yang berarti tergolong dalam kategori "baik".

Pada rumusan indikator kejelasan perumusan tujuan pembelajaran (tidak menimbulkan penafsiran ganda dan mengandung perilaku hasil belajar). Tergolong dalam kategori cukup. Pemilihan materi ajar (sesuai dengan tujuan dan karakteristik peserta didik). Tergolong dalam kategori kurang. 


\section{Hasil Penelitian Siklus II}

Berikut hasil observasi penilaian Rencana Pelaksanaan Pembelajaran guru pada siklus II:

Tabel 2 Hasil Observasi penilaian RPP untuk guru pada Siklus II

\begin{tabular}{|c|c|c|}
\hline No & Indikator Aspek yang diamati & Skor \\
\hline 1. & $\begin{array}{l}\text { Kejelasan perumusan tujuan pembelajaran (tidak } \\
\text { menimbulkan penafsiran ganda dan mengandung } \\
\text { perilaku hasil belajar). }\end{array}$ & 5 \\
\hline 2. & $\begin{array}{l}\text { Pemilihan materi ajar (sesuai dengan tujuan dan } \\
\text { karakteristik peserta didik). }\end{array}$ & 4 \\
\hline 3. & $\begin{array}{l}\text { Pengorganisasian materi ajar (keruntutan, sistematika } \\
\text { materi dan kesesuaian dengan alokasi waktu). }\end{array}$ & 5 \\
\hline 4. & $\begin{array}{l}\text { Pemilihan sumber/media pembelajaran (sesuai dengan } \\
\text { tujuan, materi dan karakteristik peserta didik). }\end{array}$ & 3 \\
\hline 5. & $\begin{array}{l}\text { Kejelasan skenario pembelajaran (setiap langkah } \\
\text { tercermin strategi/metode dan alokasi waktu pada } \\
\text { setiap tahap). }\end{array}$ & 4 \\
\hline 6. & $\begin{array}{l}\text { Kerincian skenario pembelajaran (setiap langkah } \\
\text { tercermin strategi/metode dan alokasi waktu pada } \\
\text { setiap tahap). }\end{array}$ & 3 \\
\hline 7. & Kesesuaian teknik dan tujuan pembelajaran & 5 \\
\hline 8. & $\begin{array}{l}\text { Kelengkapan instrumen (soal, kunci, pedoman } \\
\text { penskoran). }\end{array}$ & 4 \\
\hline & Skor Total & 33 \\
\hline & $\begin{array}{l}\text { Persentase nilai RPP } \sum \text { Skor Total } \times 100 \% \\
\text { ¿Skor maksimal seluruh aktifitas }(40)\end{array}$ & $82,5 \%$ \\
\hline
\end{tabular}

\section{Sumber: di olah Peneliti (2015)}

$$
\begin{aligned}
& \text { Kriteria: } \\
& 5=\text { Sangat Baik } \\
& 4=\text { Baik } \\
& 3=\text { Cukup } \\
& 2=\text { Kurang } \\
& 1=\text { Sangat Kurang }
\end{aligned}
$$

$$
\begin{aligned}
& \text { Penilaian: } \\
& 80 \%-100 \%=\text { Sangat Baik } \\
& 60 \%-79,9 \%=\text { Baik } \\
& 40 \%-59,9 \%=\text { Cukup } \\
& 20 \%-39,9 \%=\text { Kurang }
\end{aligned}
$$

Berdasarkan hasil observasi penilaian rencana pelaksanaan pembelajaran (RPP) untuk guru peneliti, pada siklus I mendapatkan jumlah persentase dengan fokus penelitian dan penilaian pada guru (peneliti). Mendapatkan jumlah persentase sebesar 82,5\% yang berarti tergolong kategori "Sangat Baik".

\section{Analisis Pelaksanaan Tindakan Kelas}

Berdasarkan hasil dari observasi peneliti di lapangan, penerapan model pembelajaran telah mampu meningkatkan hasil belajar peserta didik pada pembelajaran PKn di kelas XI IPS 3. Hal tersebut dapat dilihat selama pelaksanaan tindakan awal, siklus 
I, dan siklus II,menunjukkan peningkatan dan pertumbuhan yang memuaskan terutama peningkatan pada siklus II.

\section{Perencanaan model pembelajaran make a match untuk meningkatkan hasil belajar}

Rencana pembelajaran yang dibuat oleh guru dengan menerapkan Model Pembelajaran make a match dalam penelitian ini yaitu RPP. RPP dalam tindakan awal, siklus I, dan siklus II dibuat oleh peneliti sekaligus guru sedangkan penilaian RPP dilakukan oleh guru observer dengan mengisi lembar observasi penilaian RPP, tercantum pada tabel 4.19 berikut ini:

Table 3 Perbandingan hasil observasi Penilaian RPP dengan model make a match

\begin{tabular}{|c|c|}
\hline $\begin{array}{c}\text { Rencana Pelaksanaan } \\
\text { Pembelajaran }\end{array}$ & Persentase \\
\hline Tindakan Awal & $45 \%$ \\
Siklus I & $65 \%$ \\
Siklus II & $82.5 \%$ \\
\hline
\end{tabular}

Dari tabel di atas, dapat dilihat adanya peningkatan jumlah presentase dari tindakan awal, siklus I, dan II. Pada tindakan awal penskoran penilain RPP yaitu 45\%, sedangkan pada siklus I sebesar $65 \%$ dan pada siklus II sebesar $82.5 \%$. Sebagaimana peneliti tampilkan pada grafik 1 , sebagai berikut:

\section{Grafik 1 Perbandingan hasil Observasi RPP dengan model Make a Match}

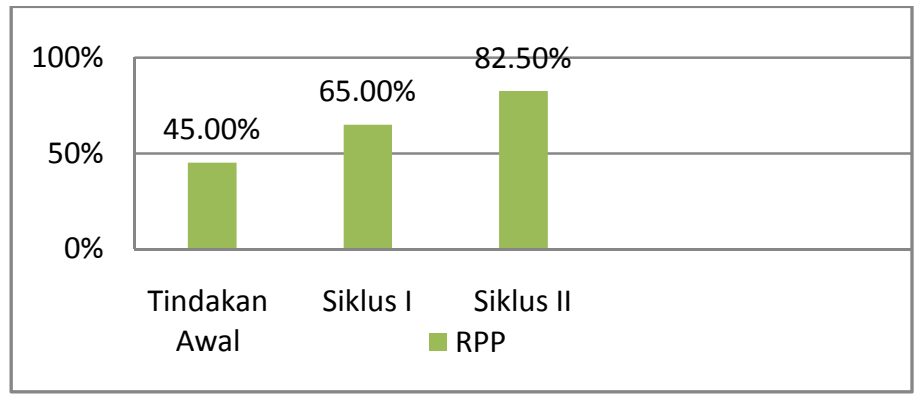

Pelaksanaan Pembelajaran dengan menerapkan Model Pembelajaran make a match pada tindakan awal, siklus I, siklus II, untuk mengetahui proses pembelajaran dengan model pembelajaran make a match ini dapat dilihat dari observasi aktivitas guru pada saat pembelajaran untuk mengetahui sejauh mana guru dapat melakukan pembelajaran dengan menggunakan model make a match. Selain itu dilihat dari observasi aktifitas peserta didik pada proses pembelajaran berlangsung untuk mengetahui kegiatan yang dilakukan peserta didik selama pembelajaran berlangsung. 
Selanjutnya, observasi aktifitas guru dilakukan dengan cara membandingkan hasil observasi aktifitas guru setiap siklus dalam bentuk persentase, sebagaimana tercantum pada tabel 4 berikut ini:

Tabel 4 perbandingan hasil observasi pelaksanaan pembelajaran dengan menerapkan model pembelajaran make a match

\begin{tabular}{|c|c|}
\hline \hline Pelaksanaan Pembelajaran & Persentase \\
\hline Tindakan Awal & $54.1 \%$ \\
Siklus I & $67.5 \%$ \\
Siklus II & $80 \%$ \\
\hline
\end{tabular}

Pada tabel 4 di atas yang berfokus pada aktifitas guru dapat terlihat adanya grafik yang meningkat dari jumlah persentase yang didapat dari hasil pengamatan yang dilakukan oleh guru mitra selama peneliti bertindak sebagai guru dari mulai tindakan awal, sampai dengan siklus II. Hal ini dapat dilihat dari tabel di atas, jumlah persentase pada tindakan awal adalah 54,16\%, siklus I berjumlah 67,5\%, dan siklus II berjumlah $80 \%$. Peneliti bertindak sebagai guru yang pada awal melakukan proses pembelajaran tanpa menerapkan model pembelajaran make a match masih tergolong dalam kategori cukup.

Pada tindakan siklus I guru dapat melakukan perubahan kearah yang lebih baik lagi berkat bantuan guru mitra yang membantu mengamati peneliti yang bertindak sebagai guru pada saat menerapkan model pembelajaran make a match pada tindakan awal, siklus I dan Siklus II sehingga dapat memberikan saran kepada peneliti tentang apa saja kekurangankekurangan peneliti pada saat melaksanakan proses pembelajaran kooperatif tipe make a match. Dan mendapatkan hasil yang bagus mendapatkan jumlah persentase yang sangat baik yaitu berjumlah $80 \%$.

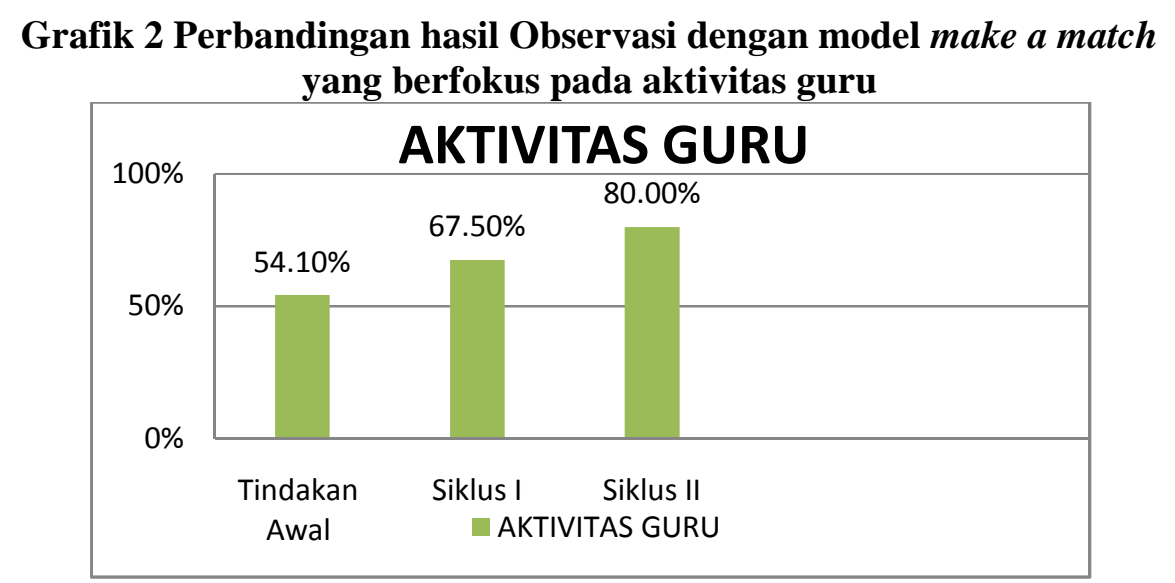




\section{Observasi aktivitas peserta didik pada pelaksanaan pembelajaran}

Sebagaimana tercantum pada tabel 5, di bawah ini:

Tabel 5 perbandingan hasil observasi berfokus pada aktifitas peserta didik

\begin{tabular}{|c|c|}
\hline Aktivitas Siswa & Persentase \\
\hline Tindakan Awal & $56.03 \%$ \\
Siklus I & $74.56 \%$ \\
Siklus II & $81.46 \%$ \\
\hline
\end{tabular}

Pada tabel di atas, siklus I dan siklus II terlihat ada peningkatan, dari tabel di atas pula, kita dapat melihat adanya peningkatan jumlah persentase. Pada tindakan awal jumlah persentase aktifitas peserta didik adalah $56.03 \%$ dengan kategori cukup, pada siklus I berjumlah 74,56\%, dengan kategori baik dan pada siklus II berjumlah 81,46\% dengan kategori sangat baik. Dalam aktivitas peserta didik terlihat adanya peningkatan yang cukup signifikan dengan persentase akhir 82,75 \% pada siklus II dengan kategori sangat baik.

Berikut ini hasil observasi pelaksanaan pembelajaran dengan fokus aktifitas pesertas didik tercantum pada grafik 4.6 berikut ini:

\section{Grafik 3 Perbandingan hasil Observasi Aktifitas Peserta didik}

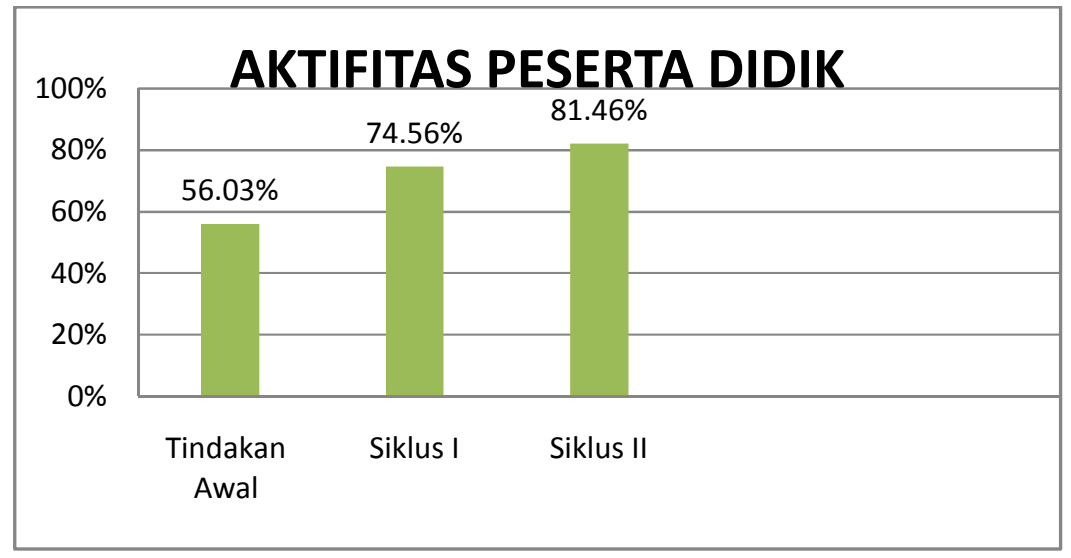

Hasil belajar peserta didik dengan model pembelajaran make a match pada tindakan awal, siklus I, dan siklus II.

Seperti pada table 6, berikut ini:

Tabel 6 perbandingan hasil belajar peserta didik pada tindakan awal, siklus I dan siklus II

\begin{tabular}{|c|c|}
\hline \hline Pelaksanaan Post Test & Persentase Ketuntasan \\
\hline Tindakan Awal & $40.74 \%$ \\
Siklus I & $65 \%$ \\
Siklus II & $82.75 \%$ \\
\hline
\end{tabular}

Sumber Di olah Peneliti (2015) 
Berdasarkan tabel di atas, dapat diketahui telah terjadi pertumbuhan hasil belajar peserta didik yang cukup signifikan pada tindakan awal, siklus I dan Siklus II. Pada tindakan awal peserta didik yang mencapai KKM hanya 8 orang atau $40.74 \%$, Pada siklus I peserta didik yang mencapai KKM 19 orang atau 65\%, pada siklus II peserta didik yang mencapai KKM 24 orang atau 82,75\%. Berikut hasil belajar peserta didik tercantum pada grafik 4, di bawah ini:

Grafik 4 Perbandingan hasil belajar peserta didik dengan model pembelajaran make a match

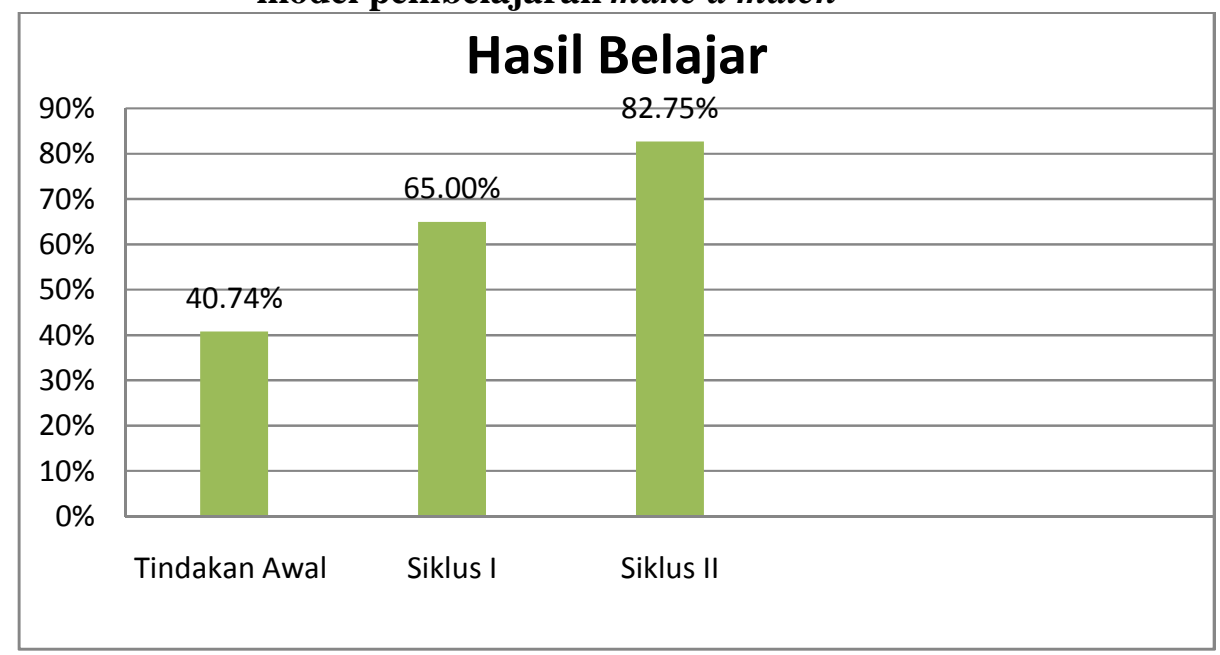

Sumber diolah Peneliti (2015)

\section{KESIMPULAN}

Berdasarkan temuan hasil penelitian mengenai penerapan model pembelajaran make a match dalam meningkatkan hasil belajar pada mata pelajaran PKn di kelas XI IPS 3 SMAN 1 Cikatomas dapat disimpulkan sebagai berikut:

1. Penerapan model pembelajaran make a match saat dan setelah tindakan dilaksanakan menunjuk bahwa dengan menggunakan model pembelajaran make a match ternyata mampu meningkatkan hasil belajar peserta didik di kelas XI IPS 3 SMAN 1 Cikatomas

2. Penerapan model pembelajaran make a match dalam pembelajaran PKN untuk meningkatkan hasil belajar peserta didik kelas XI IPS 3 dengan dua siklus,dan setiap siklusnya diperoleh dengan peningkatan yang cukup signifikan.

3. Hambatan yang dihadapi dalam implementasi metode penerapan model pembelajaran make a match pada mata pelajaran PKn adalah:

(a) Guru terlalu terpaku dengan metode ceramah karena dianggap terlalu mudah dan praktis dalam memberikan materi kepada peserta didik 
(b) sulitnya guru dalam merumuskan masalah-masalah actual pada setiap materi pelajaran;

(c) masih terdapat peserta didik yang kurang aktif dalam pembelajaran dikelas

(d) keterbatasan waktu sehingga peserta didik masih tidak leluasa dalam diskusi dan presentasi kelompok.

4. Upaya mengatasi hambatan yang dihadapi guru dalam penerapan model pembelajaran make a match adalah:

(a) Optimalisasi peran guru dapat dilakukan dengan meningkatkan kemampuan professional melalui pelatihan dan penataran;

(b) Guru harus lebih mampu mencari masalah sosial yang lebih bervariatif, menarik, dan member kesempatan kepada peserta didik untuk menyampaikan argumennya;

(c) Guru berusaha lebih baik lagi dalam menjalankan perannya sebagai fasilitator dengan lebih menggali segala potensi yang ada pada diri peserta didik;

(d) Guru harus lebih mampu mengatur waktu dengan baik sehingga pembelajaran berjalan dengan efektif.

\section{DAFTAR PUSTAKA}

Aunurrahman. ( 2011). Belajar dan Pembelajaran. Bandung: Alfabeta

Asmani, Jamal Ma'mur. (2013). 7 Tips Aplikasi PAIKEM (Pembelajaran Aktif, Kreatif, Efektif, dan menyenangkan). Jogjakarta: DIVA Press.

Arikunto, S. (2011). Penelitian Tindakan Kelas. Jakarta: Bumi Aksara.

Arikunto, S. (2005). Dasar-dasar Evaluasi Pendidikan. Jakarta: PT Bumi Aksara.

Aqib, Zainal (2013). Model-Model, Media dan Strategi Pembelajaran Kontektual (Inovativ). Bandung: Yrama Widya

Dasim, Budimansyah. (2010). Penguatan Pendidikan Kewarganegaraan untuk Menbangun Karakter Bangsa . Bandung: Widya Aksara Press.

Departemen Pendidikan Nasional. (2004). Undang-Undang No 20 Tahun 2003. Sistem Pendidikan Nasional Pasal 3. Jakarta: Depdiknas.

Ekawarna. (2013). Penelitian Tindakan Kelas. Jakarta selatan: Referensi (GP Press Group).

Huda, Miftahul (2013). Model-Model Pengajaran dan Pembelajaran.Yogyakarta: Pustaka Pelajar 
Khanifatul. (2013). Pembelajaran Inovatif. Jogyakarta: Ar-Ruzz Media.

Kemendibud RI (2014). Pendidikan Pancasila dan Kewarganegaraan untuk SMAMA/SMK Kelas XI. Jakarta: Kemendibud

Kusnandar. (2013). Penilaian Autentik (Penilaian Hasil Belajar Peserta Didik Berdasarkan Kurikulum 2013). Jakarta: Rajawali Pers.

Pamilu, Anik.(2007). Mendidik Anak Sejak dalam kandungan.Yogyakarta: Citra Media

Sumarsono, dkk. (2008). Pendidikan Kewarganegaraan. Jakarta: PT Gramedia Pustaka Utama.

Sabigin, Cecep Dudi Muklis. (2009). Pengantar Pendidikan Kewarganegaraan. Bandung: CV Insan mandiri.

Suprijono, Agus. (2013). Cooperative Learning. Yogyakarta: Pustaka Pelajar.

Suyadi. (2012). Panduan penelitian Tindakan kelas. Jogjakarta: Diva Press.

Tim. (2015). Panduan Penyusunan Proposal Skripsi, Skripsi Dan Artikel Jurnal Ilmiah. Bandung: Pelangi Press.

Tim, (2015). Panduan Praktik Pengalaman Lapangan. Bandung: Tidak di terbitkan.

Wuryan, Sri. \& Syaifullah. (2008). Ilmu Kewarganegaraan. Bandung: Laboratorium Pendidikan Kewarganegaraan.

Winarno. (2013). Pembelajaran Pendidikan Kewarganegaraan. Jakarta: Bumi Aksara. 